\title{
Function of NF-кB/Rel Binding Sites in the Major Histocompatibility Complex Class II Invariant Chain Promoter Is Dependent on Cell-Specific Binding of Different NF-кB/Rel Subunits
}

\author{
ADRIENNE M. BROWN,${ }^{1,2} \dagger$ MICHAEL W. LINHOFF, ${ }^{1,2}$ BERND STEIN,${ }^{2} \ddagger$ KENNETH L. WRIGHT, ${ }^{2}$ \\ ALBERT S. BALDWIN, JR., ${ }^{2}$ PATRICIA V. BASTA, ${ }^{3}$ AND JENNY P.-Y. TING ${ }^{1,2 *}$ \\ Department of Microbiology and Immunology ${ }^{1}$ and Lineberger Comprehensive Cancer Center, ${ }^{2}$ University of \\ North Carolina at Chapel Hill, Chapel Hill, North Carolina 27599-7295, and Research \\ Triangle Institute, Research Triangle Park, North Carolina $27709^{3}$
}

Received 25 August 1993/Returned for modification 16 November 1993/Accepted 27 January 1994

\begin{abstract}
The promoter of the human major histocompatibility complex class II-associated invariant-chain gene (Ii)

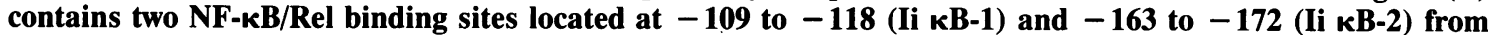
the transcription start site. We report here that the differential function of each of these $\mathrm{NF}-\kappa \mathrm{B} / \mathrm{Rel}$ sites in several distinct cell types depends on cell-specific binding of NF-kB/Rel transcription factors. Ii $\kappa B-1$ is a positive regulatory element in B-cell lines and in the Ii-expressing T-cell line, H9, but acts as a negative regulatory element in myelomonocytic and glial cell lines. In vivo protein-DNA contacts are detectable at Ii KB-1 in cell lines in which this site is functional as either a positive or negative regulator. Electrophoretic mobility supershift assays determine that members of the NF-kB/Rel family of transcription factors can bind to this site in vitro and that DNA-binding complexes that contain p50, p52, p65, and cRel correlate with positive regulation whereas the presence of $\mathbf{p 5 0}$ correlates with negative regulation. $\mathrm{Ii} \kappa \mathrm{B}-2$ is a site of positive regulation in B-cell lines and a site of negative regulation in $\mathbf{H 9} \mathrm{T}$ cells, myelomonocytic, and glial cell lines. In vivo occupancy of this site is observed only in the $\mathrm{H9}$ T-cell line. Again, in vitro supershift studies indicate that the presence of p50, p52, p65, and cRel correlates with positive function whereas the presence of only p50 and $\mathbf{p 2}$ correlates with negative function. This differential binding of specific NF-KB/Rel subunits is likely to mediate the disparate functions of these two NF-kB/Rel binding sites.
\end{abstract}

Proper functioning of major histocompatibility complex (MHC) antigens is critical to the immune response. The presence of the MHC class II-associated invariant chain (Ii) is required for the proper structure and function of MHC class II molecules. This was recently illustrated by the analysis of Ii-negative mice produced by gene ablation technology. These mice were deficient in class II function, had altered class II structure, and were deficient in T-cell development (49). The function of $\mathrm{Ii}$ is mediated by its binding to MHC class II heterodimers in the endoplasmic reticulum. This blocks peptide binding to class II during transport until the complexes reach endosomes, where Ii dissociates, thereby releasing the heterodimers in the mature and correct conformation for binding antigenic peptides (13). The MHC class II-antigen complex can then be recognized by $\mathrm{T}$-cell receptors which initiate specific helper $\mathrm{T}$-cell functions and cytokine production.

Although the Ii gene and the class II genes are encoded on separate chromosomes and their structures are unrelated, these genes are to a large extent coordinately regulated. They are expressed on the same cell types, generally B lymphocytes and antigen-presenting cells, and they are coordinately in-

\footnotetext{
* Corresponding author. Mailing address: Lineberger Comprehensive Cancer Center, CB 7295, University of North Carolina at Chapel Hill, Chapel Hill, NC 27599-7295. Phone: (919) 966-5538. Fax: (919) 966-3015.

$\dagger$ Present address: Molecular Neurobiology Laboratory, The Salk Institute for Biological Sciences, San Diego, CA 92186.

$\ddagger$ Present address: Signal Pharmaceuticals, San Diego, CA 92121.
}

duced by cytokines. Coregulation is accomplished through common cis-acting DNA sequences in their promoters $(11,17$, 19, 52). Specifically, the class II promoters and Ii share three regulatory elements: $\mathrm{S}$ (also termed $\mathrm{H}, \mathrm{W}$, or $\mathrm{Z}$ ), $\mathrm{X}$, and $\mathrm{Y}$, which mediate high constitutive expression in B lymphocytes and gamma interferon (IFN- $\gamma$ )-inducible expression $(8,22)$. However, in several situations the Ii and class II genes are also differentially regulated $(29,34,35)$. A notable instance is that the lymphocytes of patients with a severe immune deficiency, bare lymphocyte syndrome, lack all MHC class II expression but do express Ii (14). The Ii gene contains within its 5' regulatory region DNA motifs that may regulate Ii expression distinct from the other MHC class II genes. The promoter of the murine Ii gene contains an SP-1-binding site and an

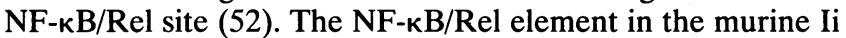
promoter mediates constitutive expression in $B$ cells (52) and mediates the tumor necrosis factor alpha (TNF- $\alpha$ ) response in fibroblasts (40). In the human Ii gene, two NF- $\kappa \mathrm{B} /$ Rel binding sites at positions -109 to -118 (Ii $\kappa \mathrm{B}-1)$ and -172 to -163 (Ii $\kappa \mathrm{B}-2$ ) from the transcription start site have been noted, but the functional role of these sites remains to be elucidated (Fig. 1) (17).

The NF-кB/Rel family of transcription factors controls the regulation of a variety of cellular and viral genes through $\mathrm{NF}-\kappa \mathrm{B} / \mathrm{Rel}$ DNA-binding site(s) in their promoters $(1,2,23)$. Members of this family that have been identified and their genes cloned include the p50 (NFKB1), p52 (NFKB2, p49, or Lyt10), and p65 (RelA) subunits of NF-kB, the proto-oncogene product $\mathrm{c}-\mathrm{Rel}$ (HIVEN86A), the avian oncogene product v-Rel, and the Drosophila morphogen Dorsal (1, 2, 23). 
NF- $\mathrm{B}$ /Rel family members share a 300 -amino-acid sequence homology, termed the Rel domain, in the N-terminal region of the proteins. The Rel domain is required for dimerization, binding to cognate DNA motifs, nuclear localization, and interaction with IкB. NF-кB exists in two forms, either constitutively expressed in the nucleus as in B cells (46) or alternatively located in the cytoplasm in association with an IKB protein. NF- $\mathrm{B}$ translocates to the nucleus upon activation by a number of inducing agents such as phorbol esters, lipopolysaccharides, interleukin-1, TNF- $\alpha$, calcium ionophores, lectin, antigen, and DNA-damaging agents such as UV light (1). NF- $\kappa B$ expression in the nucleus is regulated by I $\kappa B$, a family of proteins including I $\mathrm{I} B \alpha(\mathrm{MAD}-3), \mathrm{I} \kappa \mathrm{B} \beta, \mathrm{I} \kappa \mathrm{B} \gamma$, and the p105 and p100 proteins (the precursors to p50 and p52, respectively). These molecules sequester NF-кB subunits in the cytoplasm and inhibit binding of NF- $\mathrm{B}$ subunits to their cognate DNA-binding sites $(9,38)$. Induction of NF-кB does not require de novo protein synthesis, is quickly responsive to external signals, and is thus ideal for regulation of genes involved in inflammation and the immune response.

This work shows in vivo genomic footprints of the Ii NF- $\mathrm{B} /$ Rel binding sites in constitutively expressing and IFN$\gamma$-inducible cell lines. Functional analyses of these sites revealed that the Ii NF- $\mathrm{B} / \mathrm{Rel}$ sites serve multiple purposes dependent on the cell type. Ii $\kappa \mathrm{B}-1$ is a positive regulatory element in $\mathrm{B}$ and $\mathrm{T}$ lymphocytes and a negative element in myelomonocytic cells and brain glial cell lines. Ii $\kappa B-2$ is a positive element in $\mathrm{B}$ cells but a negative element in the Ii-expressing $\mathrm{T}$-cell line $\mathrm{H} 9$ and brain glial and myelomonocytic cell lines. Nuclear extracts from different cell types formed different complexes with these NF-kB/Rel sites, and these complexes are composed of different NF-kB/Rel transcription factors. The difference in the composition of the Ii $\kappa \mathrm{B}-1$ and $\kappa \mathrm{B}-2$ complexes may explain the opposite function served by these NF- $\mathrm{KB} / \mathrm{Rel}$ sites in vivo.

\section{MATERIALS AND METHODS}

Plasmids. The Ii promoter-CAT plasmid 790IiCAT has been described previously (11), it contains the Ii sequence from positions -790 to +1 cloned immediately upstream of the bacterial chloramphenicol acetyltransferase (CAT) gene. Constructs with mutant promoter elements were obtained by oligonucleotide-directed site-specific mutagenesis with a uracil-containing template (32). In plasmid Mut $\kappa B-1$, the sequence from -109 to -118 bp of the Ii gene was changed from 5'-GGGGTATTTCC-3' to 5'-TTTTTCTAGAA-3'. In Mut кB-2, the sequence from -172 to -163 bp was changed from $5^{\prime}$-GGGGAGCCCC-3' to 5'-CCATGGCCCC-3'. The plasmid Ii $\kappa \mathrm{B}-1 \mathrm{~m} 3$ mutates Ii $\kappa \mathrm{B}-1$ from $5^{\prime}$ GGGGTATT TCC-3' to 5'-GCACTATTTCC-3'. The plasmids $\kappa$ B-1TKCAT and $\kappa$ B-2TKCAT contain Ii $\kappa$ B-1 and Ii $к \mathrm{~B}-2$ sites, respectively, sites inserted between the HindIII and BamHI restriction enzyme sites upstream of the thymidine kinase (TK) promoter in pBLCAT4 (48). All mutations were confirmed by DNA sequence analysis.

Cell cultures. Raji is an Epstein-Barr virus-transformed human B-lymphoblastoid cell line. H9 (derived from HuT78) is an Ii/MHC class II-positive transformed human T-cell line, and Jurkat is an Ii/MHC class II-negative human T-cell line. U937 is an Ii-positive, class II-negative immature monocytic cell line isolated from a patient with histiocytic lymphoma, and WEHI-3 is a murine myelomonocytic line. All lymphoid and monocytic cell lines were maintained in RPMI 1640 supplemented with $10 \%$ fetal bovine serum and $2 \mathrm{mM}$ glutamine. WEHI-3 was additionally supplemented with $5 \times 10^{-5} \mathrm{M}$ $\beta$-mercaptoethanol. U-105 MG, previously referred to as $\mathrm{U}-373 \mathrm{MG}$ in this laboratory, is a human glioblastoma multiforme cell line and was maintained in McCoy's 5A medium$10 \%$ fetal bovine serum- $2 \mathrm{mM}$ glutamine. Primary cell cultures of rat type I astrocytes were obtained as described previously (44). Briefly, cells were cultured from the cerebral cortex of 1to 2-day-old neonatal Sprague-Dawley rats. Cells were grown for 2 to 4 weeks, until confluent, and type I astrocytes were purified by a regime of shaking and differential adherence to flasks. Cells were grown in Dulbecco's modified Eagle's medium-10\% fetal bovine serum-2 mM glutamine-100 U of penicillin per ml-100 mg of streptomycin per ml. Glioblastoma cells were treated with $500 \mathrm{U}$ of recombinant human IFN- $\gamma$ per ml, which was generously provided by Biogen, Cambridge, Mass.

Transfection and CAT assay. Transfection of various cell lines was performed by electroporation as previously described (11). Extracts for CAT assays were prepared from the transfected cells, and protein concentrations were determined by the Bradford method (10). Extracts were tested for CAT activity by using $\left[{ }^{3} \mathrm{H}\right]$ acetyl coenzyme A (37).

In vivo genomic footprinting. The dimethyl sulfate treatment of cell cultures, DNA preparation, and ligation-mediated PCR were performed as described previously $(36,50)$. The invariant chain-specific primers were as follows (from $5^{\prime}$ to $3^{\prime}$ ): for the proximal $150 \mathrm{bp}$, the coding strand (upper strand), primer 1, ATTGTTGGAGATAAGGTCA; primer 2, AT GACTGGCTTCTGATCTTCCCGACAGC; primer 3, ACT GGCTTCTGATCTTCCCGACAGCTCCTG; and the noncoding strand (lower strand), primer 1, GCCCAGAAA CAAGTGATGAG; primer 2, GGATCGTGCTGGCCTTTC TACCTGC; primer 3, GGATCGTGCTGGCCTTTCTACCT GCCTG; for the distal $150 \mathrm{bp}$, the coding strand (upper strand), primer 1, CTCTTAAAGTCGGTGCTG; primer 2, GCCACTCCGCCCACTTGGTAGATGTG; primer 3, CACTCCGCCCACTTGGTAGATGTGGAAGTG; and the noncoding strand (lower strand), primer 1, TGAGAAGGG GAGACAAAC; primer 2, CAAAGTGCTTTCCTGTCTA GGGAGTGGAC; primer 3, GTGCTTTCCTGTCTAGGG AGTGGACATTTGC.

Nuclear run-on transcription. Nuclear transcription and hybridization were performed as previously described (51). Briefly, the cells were treated with $500 \mathrm{U}$ of recombinant human IFN- $\gamma$ for $0,24,48$, and $72 \mathrm{~h}$, harvested, and lysed in high-pH buffer with $0.05 \%$ Nonidet P-40. The nuclei were washed and labeled with $\left.{ }^{32} \mathrm{P}\right] \mathrm{UTP}$ (ICN, Boston, Mass.) in a $100-\mu l$ reaction for $15 \mathrm{~min}$ at $30^{\circ} \mathrm{C}$. The labeled nuclei were treated with DNase, extracted with hot $\left(60^{\circ} \mathrm{C}\right)$ phenol-chloroform-isoamyl alcohol (1:1:0.01), and concentrated by ethanol precipitation. The labeled RNA was treated with $0.2 \mathrm{M} \mathrm{NaOH}$ and hybridized to DNA immobilized on nitrocellulose filters at $40^{\circ} \mathrm{C}$. The hybridized material was quantitated with a Molecular Dynamics PhosphorImager.

Nuclear extract preparation and EMSA. The nuclear extracts were prepared by a previously described method (7) with the following modifications. The cell lysis buffer consisted of $10 \mathrm{mM} N$-2-hydroxyethylpiperazine- $N^{\prime}$-2-ethanesulfonic acid (HEPES; pH 7.9), $60 \mathrm{mM} \mathrm{KCl,} 0.75 \mathrm{mM}$ spermidine, $0.15 \mathrm{mM}$ spermine, $1 \mathrm{mM}$ dithiothreitol, $0.1 \mathrm{mM}$ EDTA, $0.1 \mathrm{mM}$ ethylene glycol-bis( $\beta$-aminoethyl ether)- $N, N-N^{\prime}, N^{\prime}$-tetraacetic acid (EGTA), and protease inhibitors (aprotinin, leupeptin, phenylmethylsulfonyl fluoride, pepstatin, and E-64). NP-40 was added to $0.2 \%$, and lysis was monitored by light microscopy. Nuclei were pelleted, washed, and resuspended in an equal volume of nuclear extract buffer $(20 \mathrm{mM}$ HEPES [pH 7.9], $60 \mathrm{mM} \mathrm{NaCl}, 0.75 \mathrm{mM}$ spermidine, $0.15 \mathrm{mM}$ spermine, $0.2 \mathrm{mM}$ EDTA, $2 \mathrm{mM}$ EGTA, $2 \mathrm{mM}$ dithiothreitol, $25 \%$ 

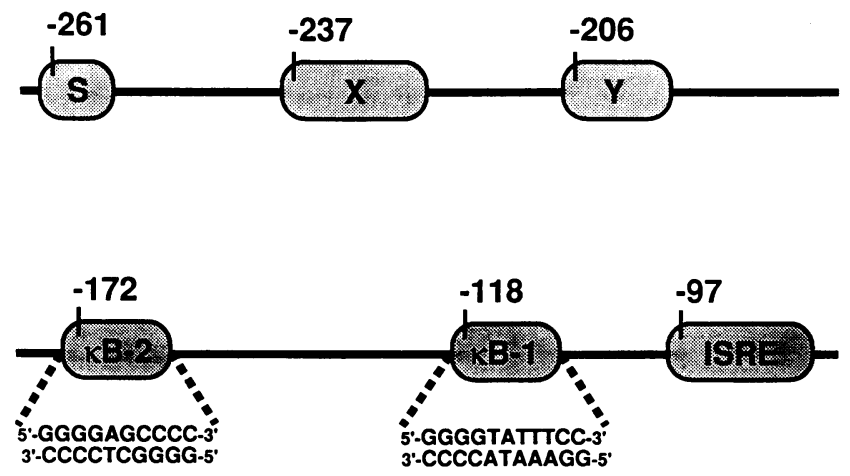

FIG. 1. Ii promoter organization. Schematic diagram of the Ii promoter from -82 to -261 bp shows the Ii regulatory elements (31). The regulatory motifs $\mathrm{S}, \mathrm{X}, \mathrm{Y}, \kappa \mathrm{B}-1, \kappa \mathrm{B}-2$, and ISRE are in shaded boxes.

glycerol, protease inhibitors). $\mathrm{NaCl}(5 \mathrm{M})$ was added to a final concentration of $400 \mathrm{mM} \mathrm{NaCl}$, and the protein concentration was determined (10). The probes were ${ }^{32} \mathrm{P}$ labeled and annealed oligonucleotides that contain the following sequence: 5'-AGCTTGGGGTATTTCCAGCCG-3' (Ii кB-1) and 5'AGCTTGGGGGAGCCCCG-3' (Ii $\kappa \mathrm{B}-2$ ) (the binding site is printed in boldface type). Antibodies to NF-кB/Rel proteins were previously described [anti-p65 (7), anti-52 (a gift from $M$. Karin), and anti-c-Rel (43)]; anti-NF-кB p50 (NL5) was purchased and used as specified by the manufacturer (Santa Cruz Biotechnology, Santa Cruz, Calif.). The bacterially expressed $\mathrm{I}_{\kappa} \mathrm{B} \alpha$ was the kind gift of Amer Beg. The binding reaction contained 5 to $10 \mu \mathrm{g}$ of nuclear extract in a buffer consisting of $10 \mathrm{mM}$ Tris (pH 7.6), $75 \mathrm{mM} \mathrm{NaCl}, 1 \mathrm{mM}$ EDTA, $1 \mathrm{mM}$ dithiothreitol, $5 \%$ glycerol, $2 \%$ Ficoll, $0.5 \mathrm{mM}$ phenylmethylsulfonyl fluoride, and $0.1 \mu \mathrm{g}$ of poly(dI-dC) per $\mu \mathrm{l}$. Antibodies and IкB protein were incubated with nuclear extracts for $2 \mathrm{~h}$ at $4^{\circ} \mathrm{C}$ before the addition of the probe. The complexes were resolved on 4 or $5 \%$ polyacrylamide gels in Tris-glycine buffer.

\section{RESULTS}

Protein-DNA interactions at the Ii NF-кB/Rel sites in vivo. In vivo genomic footprinting is a powerful approach that examines the occupancy of DNA regulatory elements by transcription factors in intact cells. A number of studies have reported that the functional regulatory units in promoters of expressed genes are bound in vivo $(5,16,27,33,36,50)$. Our previous analyses by genomic footprinting have revealed that the in vivo protein-DNA interactions and function of the Ii regulatory elements $\mathrm{X}$ and $\mathrm{Y}$ correlate precisely with the expression of the Ii gene in various cell types (12). We have analyzed in vivo protein binding at two Ii NF- $\mathrm{kB} / \mathrm{Rel}$ binding sites in B-cell lines, nonexpressing $\mathrm{T}$-cell lines, the Ii-positive T-cell line $\mathrm{H} 9$, and IFN- $\gamma$-induced and uninduced glioblastoma cells. The NF- $\kappa \mathrm{B} / \mathrm{Rel}$ site proximal to the Ii transcription start at sequence -109 to -118 is referred to as $\mathrm{Ii} \kappa \mathrm{B}-1$, and the distal site at sequence -163 to -172 is referred to as Ii $\kappa \mathrm{B}-2$ (Fig. 1).

Figure 2 shows the results of the in vivo dimethyl sulfate footprinting. Proteins contacted $\mathrm{G}$ residues in the $\mathrm{Ii} \kappa \mathrm{B}-1$ element in the B-cell line Raji (Fig. 2, top panel, lanes 1 and 2), in $\mathrm{H} 9 \mathrm{~T}$ cells (lanes 3 and 4), but not in the Ii-negative Jurkat cells (lanes 5 and 6). Another Ii-positive B-cell line, Namalwa, and another negative T-cell line, HSB, gave identical results to the Raji and Jurkat lines, respectively (data not shown). These
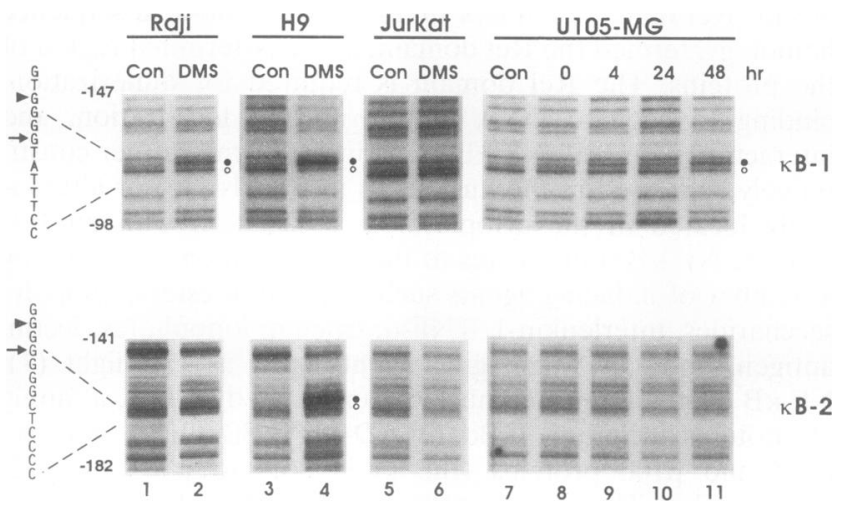

FIG. 2. In vivo genomic footprint of Ii NF- $\mathrm{kB} / \mathrm{Rel}$ binding sites. Footprint of the Ii $\kappa B$ sites in the region from -98 to -147 (top panel) and -141 to -182 (bottom panel) of the Ii promoter with DNA from Raji (lanes 1 and 2), H9 (lanes 3 and 4), Jurkat (lanes 5 and 6), and IFN- $\gamma$-treated U-105 MG at 0, 4, 24, and $48 \mathrm{~h}$ (lanes 7 to 11). A footprint of the region surrounding each NF- $\mathrm{KB} / \mathrm{Rel}$ homolog and the nucleotide sequence of each NF- $\mathrm{kB} / \mathrm{Rel}$ site are shown. Lanes Con and DMS are DNA methylated in vitro and in vivo, respectively. Open circles mark positions of protections, and solid circles mark positions of enhancements.

observations indicate that the in vivo binding to this site segregates with expression in these cell types and implicates the importance of this element in Ii gene regulation. In addition to the constitutive mode of Ii expression, the occupancy of the Ii кB-1 site was also examined upon induction by IFN- $\gamma$ in the glioblastoma cell line U-105 MG. Ii in this cell line is inducible to high levels over basal expression by IFN- $\gamma$. The Ii $\kappa$ B-1 element was unbound in uninduced U-105 MG glioblastoma cells (Fig. 2, top panel, lane 7). Interestingly, after IFN- $\gamma$ treatment, a pattern of protections and an enhancement appear over the Ii кB-1 site in the glioblastoma cells (lanes 8 to 11). These bands become most intense by $48 \mathrm{~h}$, whereupon the pattern resembled the pattern observed on Ii $\kappa$ B-1 in Raji and H9 cells.

Ii $\kappa \mathrm{B}-2$ had no detectable protein contacts in Raji cells, Jurkat cells, or U-105 MG cells with or without IFN- $\gamma$ (Fig. 2, bottom panel). In striking contrast, pronounced binding was detected on Ii кB-2 in H9 cells (lanes 3 and 4). Interestingly, recent findings show in vitro binding to a human immunodeficiency virus $\kappa B$ probe in nuclear extracts from H9 cells (41).

Ii NF-кB/Rel elements have positive or negative regulatory activity depending on the cell type. NF- $\mathrm{B} / \mathrm{Rel}$ binding sites control transcription in a number of other immune response genes, and the genomic footprinting results suggest that the Ii $\mathrm{NF}-\kappa \mathrm{B} / \mathrm{Rel}$ sites may have a role in the transcription of the Ii gene. To determine the functional role of Ii $\kappa$ B-1 and Ii $\kappa$ B-2, the two sites were individually mutated in the context of the -790 Ii promoter region (790IiCAT plasmid) and the promoter-CAT constructs were designated Mut кB-1 and Mut кB-2, respectively. The wild-type and mutant plasmids were transfected into cell lines representing various cell types, cell extracts were prepared, and CAT assays were performed. The activity of each mutant was normalized to the wild-type (790IiCAT) construct. Analysis by transfection into Ii-expressing Raji B lymphoblastoid cells was straightforward and showed that mutation of Ii $\mathrm{kB}-1$ resulted in a loss of transcription to $44 \%$ of wild-type activity whereas mutation at Ii кB-2 resulted in a loss of $53 \%$ of wild-type activity (Fig. 3). Mutation of both sites resulted in $28 \%$ of wild-type activity (data not 


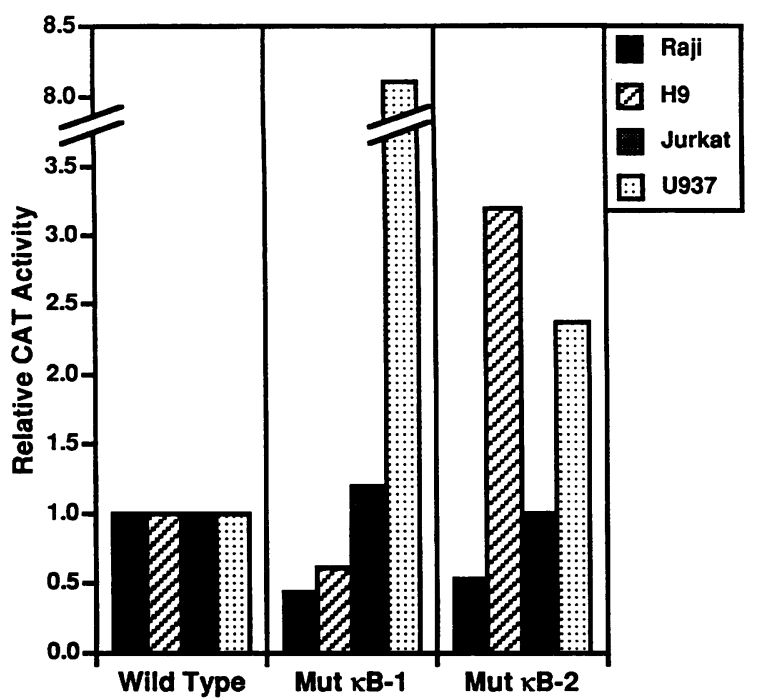

FIG. 3. Ii $\kappa \mathrm{B}-1$ and Ii $\kappa \mathrm{B}-2$ have positive and negative regulatory functions depending on the cell type. Transient-transfection and CAT assays were performed with plasmids containing wild-type Ii promoter and Ii promoter with mutant Ii $\mathrm{kB}$ sites in Raji, H9, Jurkat, and U937 cells. Raji, H9, and Jurkat cells were transfected with $5 \mu \mathrm{g}$ of each plasmid DNA, and U937 cells were transfected with $8 \mu \mathrm{g}$ of DNA. The mean CAT activity obtained for each mutant $(n>5)$ is normalized to that obtained for the wild-type plasmid (790IiCAT), which is expressed as $100 \%$ CAT activity. The mean CAT activity of the wild-type construct in each cell line is as follows: Raji, 130,158 cpm; H9, 222,813 cpm; Jurkat, 26,178 cpm; and U937, 3,591 cpm.

shown). When assayed in Namalwa, another B-lymphoblastoid cell line, similar results were obtained to those obtained with the Raji cell line (data not shown). Interestingly, whereas in vivo occupancy of Ii $\mathrm{kB}-1$ in Raji cells was clearly demonstrated, Ii кB-2 occupancy was not observed (Fig. 2, botton panel, lanes 1 and 2). It is possible that protein binding occurs at this site but escapes detection because of the nature of the assay or the protein-DNA interaction; this topic is discussed in more detail below (see the discussion of Fig. 8 and 9). These results indicate that in addition to the classical MHC class II promoter elements, S, X, and Y (12), the Ii NF-kB/Rel sites contribute to the high levels of Ii expression in B cells.

Although most $\mathrm{T}$ cells do not express the Ii and MHC class II antigens, activated human $\mathrm{T}$ cells and the human $\mathrm{T}$-cell line
H9 (HUT78) do express these genes. Mutation of Ii кB-1 reduced CAT activity in transfected $\mathrm{H} 9$ cells to $61 \%$ of control activity (Fig. 3). Similar results were observed when a more conservative Ii $\kappa \mathrm{B}-1$ mutation ( $\kappa \mathrm{B}-1 \mathrm{~m} 3$; data not shown) was used. Unexpectedly, when Ii $\kappa \mathrm{B}-2$ was analyzed, CAT activity was increased threefold over wild-type levels by mutating this site (Fig. 3). In vivo occupancy of this site was unique to $\mathrm{H} 9$ cells (Fig. 2, bottom panel). Thus in the H9 T cells, Ii кB-1 and Ii $\mathrm{kB}-2$ appear to be positive and negative regulatory elements, respectively, and both positive and negative sites are occupied in vivo. Analysis of the Ii-negative T-cell line Jurkat revealed no function for Ii NF- $\mathrm{kB} / \mathrm{Rel}$ sites in Ii gene promoter regulation since mutation of either site did not significantly change basal levels of expression (Fig. 3). These results agree with the lack of in vivo binding over these sites in Jurkat cells and are expected because NF-кB is cytoplasmic in nonactivated Jurkat cells (1). When these cells are stimulated with phorbol ester, $\mathrm{NF}-\kappa \mathrm{B}$ activity is detected in the nucleus.

To broadly ascertain the function of the NF-kB/Rel sites, we examined several other cell lines. In the human promonocytic cell line U937 (Fig. 3), the murine myelomonocytic line WEHI-3 (data not shown), and the human cervical carcinoma line HeLa (data not shown), the mutation of the Ii кB-1binding site resulted in a substantial increase in transcriptional activity and typically increased promoter activity by 8- to 10 -fold. In addition, as in the $\mathrm{H} 9$ cells, mutation of $\mathrm{Ii} \kappa \mathrm{B}-2$ increased the basal levels of expression in U937 cells (Fig. 3). In summary, Ii $\kappa \mathrm{B}-1$ contributes to basal activation in $\mathrm{B}$ lymphocytes and $\mathrm{H} 9 \mathrm{~T}$ cells and to basal repression in epithelial and monocytic cell types. Ii $\kappa \mathrm{B}-2$ functions as an activator in B cells and as a repressor in H9 cells and U937 cell lines (summarized in Table 1).

The effect of mutation of Ii $\kappa \mathrm{B}-1$ and $\kappa \mathrm{B}-2$ on Ii induction by IFN- $\gamma$ in glioblastoma U-105 MG cells was also examined. The Ii S, X, Y, and ISRE are required for IFN- $\gamma$ induction of the Ii gene in U-105 MG cells $(4,11)$. We were therefore interested in whether the Ii NF- $\mathrm{kB} / \mathrm{Rel}$ sites play a role in the IFN- $\gamma$ response. When absolute values were compared, mutation of either Ii $\kappa$ B-1 or Ii $\kappa$ B-2 produced a threefold increase in relative CAT activity for both basal levels and IFN- $\gamma$-induced levels (Fig. 4). This increase in Ii gene expression indicates that the Ii NF- $\mathrm{B}$ /Rel binding sites have a negative effect on basal transcription in the glioblastoma cell line. Since there was no significant change in fold induction (Fig. 4), our data demonstrate that the two NF- $\mathrm{kB} / \mathrm{Rel}$ sites are not necessary for IFN- $\gamma$ regulation. This is in contrast to the Ii S, X, and Y elements,

TABLE 1. Summary of Ii NF-kB/Rel activities

\begin{tabular}{|c|c|c|c|c|c|c|c|}
\hline \multirow{2}{*}{ кB site } & \multirow{2}{*}{ Cell line } & \multicolumn{4}{|c|}{ Presence of antibody supershifted complex ${ }^{a}$} & \multirow{2}{*}{$\begin{array}{l}\text { Transcriptional } \\
\text { regulation }^{b}\end{array}$} & \multirow{2}{*}{$\begin{array}{l}\text { In vivo } \\
\text { occupancy }\end{array}$} \\
\hline & & $\alpha-$ p65 & $\alpha-p 50$ & $\alpha-\mathrm{p} 52$ & $\alpha-c-$ Rel & & \\
\hline \multirow[t]{4}{*}{$\kappa \mathrm{B}-1$} & Raji & + & ++ & ++ & ++ & A & + \\
\hline & $\mathrm{H} 9$ & + & +++ & ++ & - & A & + \\
\hline & U937 & - & + & - & - & $\mathbf{R}$ & $\mathrm{ND}^{c}$ \\
\hline & U105-MG & - & - & - & - & $\mathbf{R}$ & $-d$ \\
\hline \multirow[t]{4}{*}{ кB-2 } & Raji & + & +++ & ++ & ++ & A & - \\
\hline & $\mathrm{H} 9$ & - & +++ & ++ & - & $\mathrm{R}$ & + \\
\hline & U937 & - & ++ & - & - & $\mathbf{R}$ & ND \\
\hline & U105-MG & - & + & - & - & $\mathbf{R}$ & - \\
\hline
\end{tabular}

${ }^{a} \alpha$ indicates "anti."

${ }^{b} \mathrm{~A}$, activation; $\mathrm{R}$, repression.

c ND, not determined.

${ }^{d}$ In vivo occupancy at this site was observed upon induction with IFN- $\gamma$. 


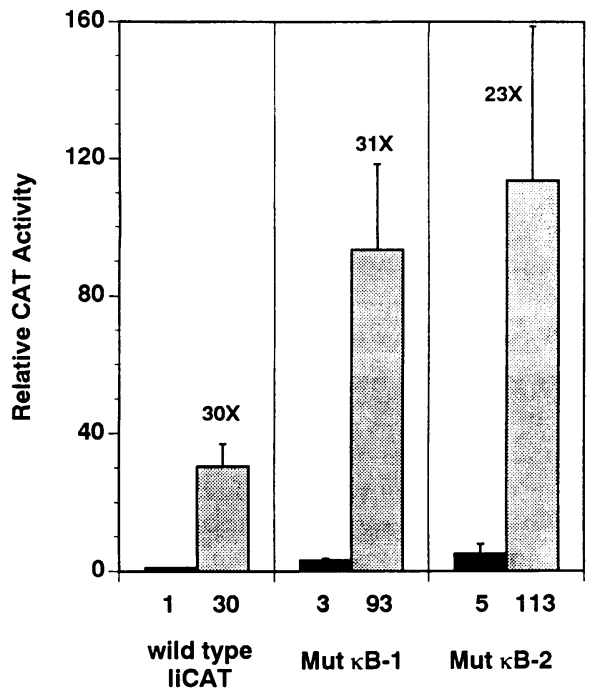

FIG. 4. Effect of mutation of Ii $\kappa \mathrm{B}-1$ and Ii $\kappa \mathrm{B}-2$ on basal and IFN- $\gamma$-induced expression in the glioblastoma cell line U-105 MG. Cells were transfected with $5 \mu \mathrm{g}$ of wild-type or mutant plasmids and treated with IFN- $\gamma$ or left untreated. CAT activity was determined at $48 \mathrm{~h}$ after treatment. The means of the relative CAT activities for each sample are shown below the bars $(n=8)$. They have been normalized to the basal activity of the wild-type construct (790IiCAT/no IFN- $\gamma$ equals 1.0). The fold induction for each plasmid is shown above the bar representing the IFN- $\gamma$-induced values. The solid and shaded bars represent basal and IFN- $\gamma$-induced expression, respectively. The error bars represent standard error of the mean.

which are all required for IFN- $\gamma$-inducible transcription in U-105 MG $(11,12)$. A similar strong derepression of basal transcription was observed when Mut $\kappa \mathrm{B}-1$ was transfected into CRT cells, a human astrocytoma cell line, and into primary untransformed rat astrocyte cultures (data not shown). These results indicate that the Ii NF- $\kappa \mathrm{B} / \mathrm{Rel}$ sites also have silencing functions in transformed and primary brain glial cells.

One curious observation is that the Ii $\kappa \mathrm{B}-1$ element is a negative regulatory element in IFN- $\gamma$-treated glioblastoma cells (Fig. 4) and, as shown by in vivo footprinting analysis, becomes bound upon IFN- $\gamma$ induction (Fig. 2, top panel, lanes 7 to 11$)$. This may indicate that the binding of protein(s) at this site is involved in repression during induction. Conceivably this repression occurs after activation because the enhancement and the protections at Ii $\kappa \mathrm{B}-1$ are most intense at $48 \mathrm{~h}$ after IFN- $\gamma$ treatment (lane 11) whereas IFN- $\gamma$-inducible binding at $\mathrm{X}, \mathrm{Y}$, and ISRE is maximal by $24 \mathrm{~h}(11)$. We propose that the timing of this interaction indicates that after transcription is induced, a protein interaction that leads to down-regulation is completed at the Ii $\kappa$ B-1 site. To study this further, we examined the rate of transcription at $0,24,48$, and $72 \mathrm{~h}$ after IFN- $\gamma$ treatment in a run-on transcription experiment. As seen in Fig. 5, Ii transcription increases up to $24 \mathrm{~h}$, plateaus at 24 to $48 \mathrm{~h}$, and finally returns to near basal levels by $72 \mathrm{~h}$. The timing of down-regulated de novo Ii mRNA synthesis immediately follows the timing of protein binding in vivo at Ii $\kappa \mathrm{B}-1$. Thus changes in in vivo occupancy at this site may be attributed to the binding of repressor protein(s).

To show that the Ii $\kappa \mathrm{B}-1$ mutation did not create a new regulatory site, we tested another mutant plasmid, $\kappa \mathrm{B}-1 \mathrm{~m} 3$, in different cell types. $\kappa \mathrm{B}-1 \mathrm{~m} 3$ is a more conservative mutation in which described NF-кB contact points (the first three G residues) were mutated (see Materials and Methods). Results
A

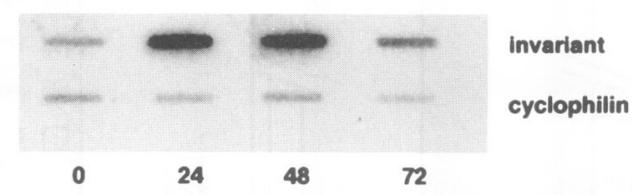

B

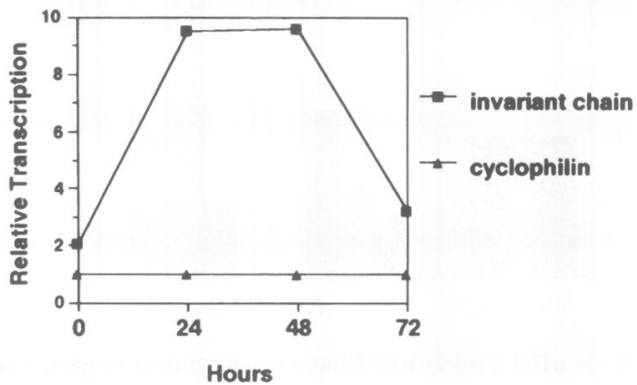

FIG. 5. Rate of transcription of Ii after IFN- $\gamma$ induction in the glioblastoma cell line, U-105 MG. The glioblastoma cells were treated with IFN- $\gamma$ for $0,24,48$, and $72 \mathrm{~h}$. Nascent mRNA was radiolabeled in vivo and hybridized to immobilized Ii or cyclophilin DNA as a control. (A) Results monitored by the PhosphorImager. (B) Values normalized relative to the cyclophilin control and plotted for each time point.

of CAT assays in Raji, $\mathrm{H} 9$, and U-105 MG cells revealed that $\kappa \mathrm{B}-1 \mathrm{~m} 3$ had similar transcriptional activity to that of Mut $\kappa \mathrm{B}-1$ (data not shown). Since two independent mutations of Ii $\kappa \mathrm{B}-1$ resulted in similar changes in Ii basal expression, it is unlikely that Mut $\kappa \mathrm{B}-1$ created another regulatory site for an activator or inhibitor protein.

Ii $\kappa B-2$ silencer acts in a heterologous promoter, but Ii $\kappa B-1$ does not. To analyze the two Ii NF-kB/Rel sites in the context of a non-Ii promoter, we made CAT reporter constructs with one of either site inserted upstream of the TK promoter. These reporter plasmids were tested by transfection and CAT assay in

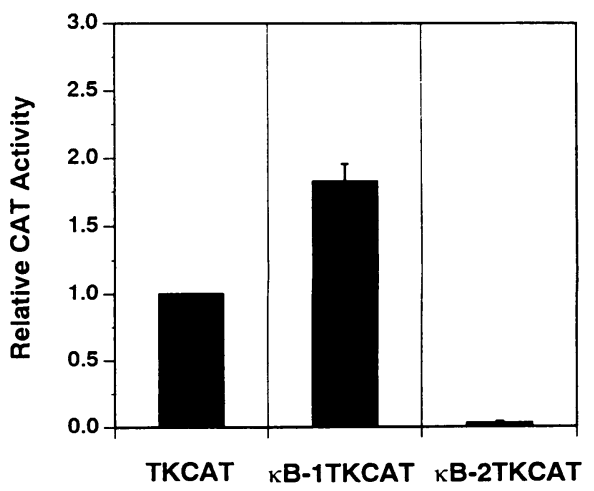

FIG. 6. Effects of Ii $\kappa B$ sites on the TK promoter. U937 cells were transfected with $8 \mu \mathrm{g}$ of the indicated plasmid. The constructs are the TK promoter upstream of the CAT gene alone (TKCAT), the Ii кB-1 linked to the TKCAT ( $\mathrm{kB}-1$ TKCAT), and the Ii $\kappa \mathrm{B}-2$ site linked to the TKCAT plasmid ( $\mathrm{kB}-2 \mathrm{TKCAT})$. At $36 \mathrm{~h}$ after transfection, the CAT activity was determined. The mean levels of CAT activity of three experiments are shown. The error bars represent standard error of the mean. 
U937 cells, in which both sites have a negative effect on Ii gene transcription within the context of its own promoter (Fig. 3). $\kappa \mathrm{B}-1 \mathrm{TKCAT}$ produced slightly increased levels of CAT activity compared with the control TKCAT plasmid (Fig. 6). However, Ii $\kappa \mathrm{B}-2$ exhibited a strong negative effect on the TK promoter, resulting in a complete loss of CAT activity. These experiments suggest that Ii $\kappa$ B-1 may be a position- or context-dependent silencer and that $\mathrm{Ii} \kappa \mathrm{B}-2$ is a silencer able to function outside the context of the Ii promoter.

In vitro binding at Ii NF-KB elements and identification of NF-кB/Rel protein subunits. We considered it likely that the positive and negative regulatory effects of the Ii NF-kB/Rel sites in different cell types were due to differential expression or binding of nuclear factors in these cells (39). We examined nuclear extracts from Raji, H9, and U937 cells by EMSA and discovered differences in the protein complexes bound by Ii NF- $\mathrm{B} / \mathrm{Rel}$ probes in these cell types. Figure 7 shows protein complexes on Ii кB-1 and Ii кB-2 probes in Raji, H9, and U937 cells; the relatedness of the complexes is demonstrated by competition with unlabeled Ii $\kappa$ B-1 and $\kappa$ B-2 oligonucleotides. Raji nuclear extracts formed four complexes with Ii $\kappa \mathrm{B}-1$ (Fig. 7A, lanes 1 to 3 ) and three distinct complexes with Ii кB-2 (Fig. 7B, lanes 1 to 3). H9 extracts formed six bands with Ii кB-1 (doublets are resolved upon shorter exposures of the gel; also see Fig. 8B) and two bands with Ii $\kappa \mathrm{B}-2$ (Fig. 7A and B, respectively, lanes 4 to 6 ). U937 extracts formed two complexes with the Ii $\kappa \mathrm{B}-1$ probe and one complex with the Ii $\kappa \mathrm{B}-2$ probe (Fig. 7A and B, respectively, lanes 7 to 9). All of these complexes were specific as shown by competition with homologous as well as unrelated oligonucleotide sequences. It is striking that each set of protein-DNA complexes is different; although some bands seem to have identical migration, other bands are unique for the corresponding extract. In summary, each Ii NF- $\mathrm{B} / \mathrm{Rel}$ site appears to bind a different pattern of complexes in each cell type.

We tested the ability of the Ii $\kappa \mathrm{B}-1$ site to bind cloned recombinant NF- $\mathrm{KB}$ proteins that had been expressed in COS cells or in vitro translation systems. The Ii $\kappa \mathrm{B}-1$ probe was able to bind p65 and p50 in the EMSA with the same mobility as that of complexes formed on an HIV $-\kappa B$ probe, whereas extracts containing expression vector alone were not (data not shown). This indicates that Ii $\kappa \mathrm{B}-1$ is able to interact with these combinations if they present. We were also interested in which NF- $\kappa \mathrm{B} / \mathrm{Rel}$ family members composed the different proteinDNA complexes on activator compared with repressor sites in the various cell lines.

To characterize the factors binding to the Ii NF-кB/Rel sites, we used specific antibodies in EMSA to identify known NF- $k B /$ Rel family proteins (see Table 1 for a summary of the data). A comparison of antibody-treated and untreated reactions with Raji nuclear extracts and Ii кB-1 shows that anti-p65 caused a weak supershifted band (Fig. 8A, lane 3 ) and addition of the peptide to which the antiserum was made abolished this complex (lane 4). The anti-p65 used in these experiments can effectively shift a TNF- $\alpha$-induced complex in HeLa nuclear extracts (7), indicating that the weak supershift obtained in these experiments is a reflection of small amounts of p65 as opposed to inadequate recognition of these complexes by the antibody. In addition, anti-p50, anti-p52, and anti-c-Rel all formed specific supershifted complexes (Fig. 8A, lanes 5 to 8). This indicates that Ii $\kappa \mathrm{B}-1$ protein-DNA complexes include all four NF- $\kappa \mathrm{B} / \mathrm{Rel}$ subunits in Raji cells. A similar analysis of Ii $\kappa \mathrm{B}-2$, the distal site, showed that the same four specific antibodies against p65, p50, p52, and c-Rel reacted with complexes in Raji extracts (Fig. 9A). Anti-p50 eliminated all complexes on this site. In summary, both sites in Raji cells are
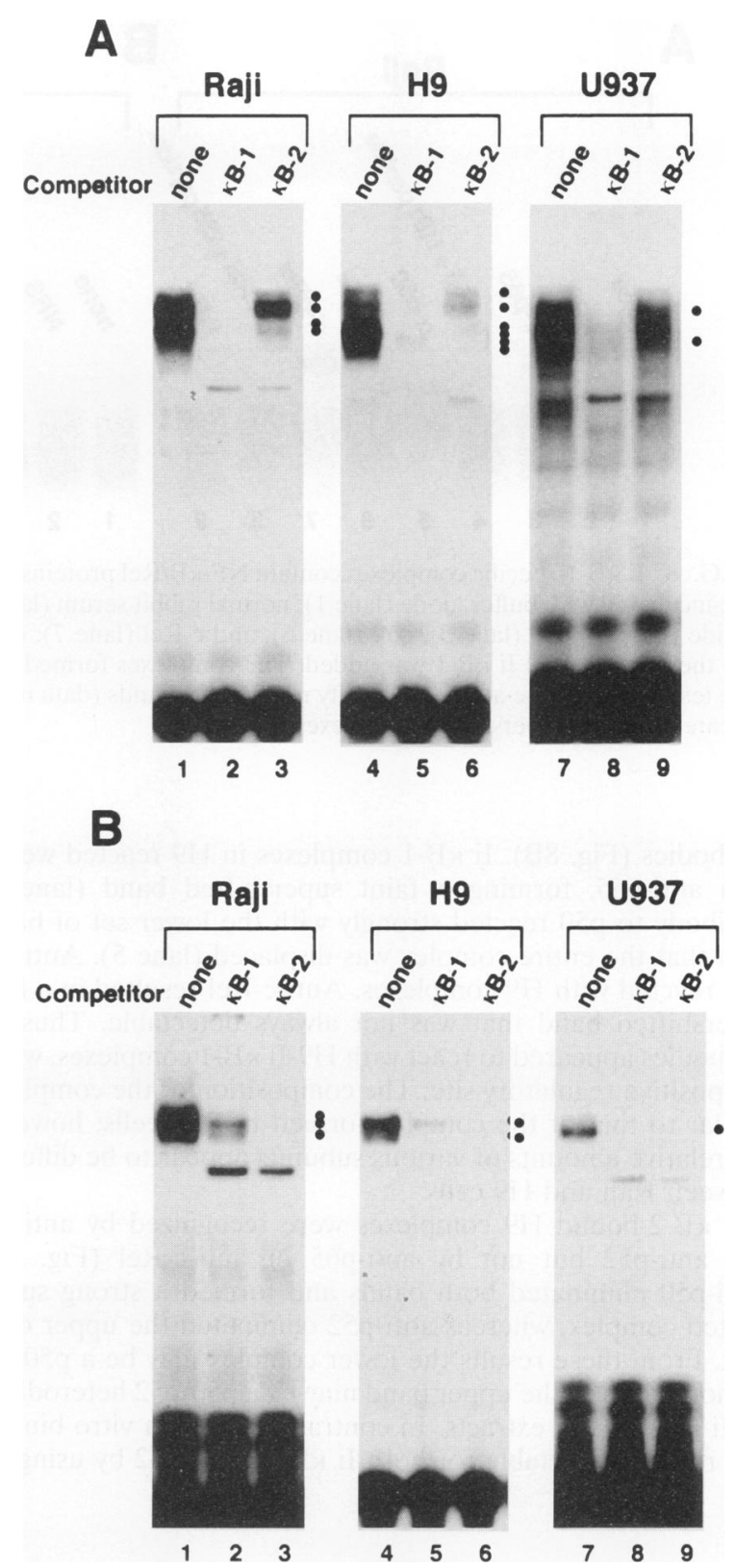

FIG. 7. Ii NF-kB/Rel sites bind complexes in nuclear extracts. Ii $\kappa \mathrm{B}-1$ (A) and Ii $\kappa \mathrm{B}-2$ (B) radiolabeled probes were incubated with nuclear extracts from Raji (lanes 1 to 3 ), H9 (lanes 4 to 6 ), and U937 (lanes 7 to 9) cells. Specific complex formation is shown by the addition of competitor oligonucleotides at 100 -fold molar excess: Ii кB-1 (lanes 2, 5, and 8) and Ii кB-2 (lanes 3, 6, and 9). Circles indicate specific complexes.

activators and all four NF- $\mathrm{B} / \mathrm{Rel}$ subunits were detected in complexes on these sites. It should be noted that binding of $\mathrm{NF}-\kappa \mathrm{B} / \mathrm{Rel}$ factors to Ii $\kappa \mathrm{B}-1$ is significantly more intense than is binding to Ii $\kappa \mathrm{B}-2$. Visible complexes with $\mathrm{Ii} \kappa \mathrm{B}-1$ were typically evident after $4 \mathrm{~h}$ of exposure, whereas complexes with Ii $\kappa \mathrm{B}-2$ appeared to be significantly weaker and required a threefold longer exposure. This may affect the ability to detect protein-DNA interactions by the genomic footprinting assay (Fig. 2).

Analysis of Ii $\kappa$ B-1 with $\mathrm{H} 9$ nuclear extracts resulted in at least six bands which were recognized by NF- $\mathrm{B} / \mathrm{Rel}$-specific 


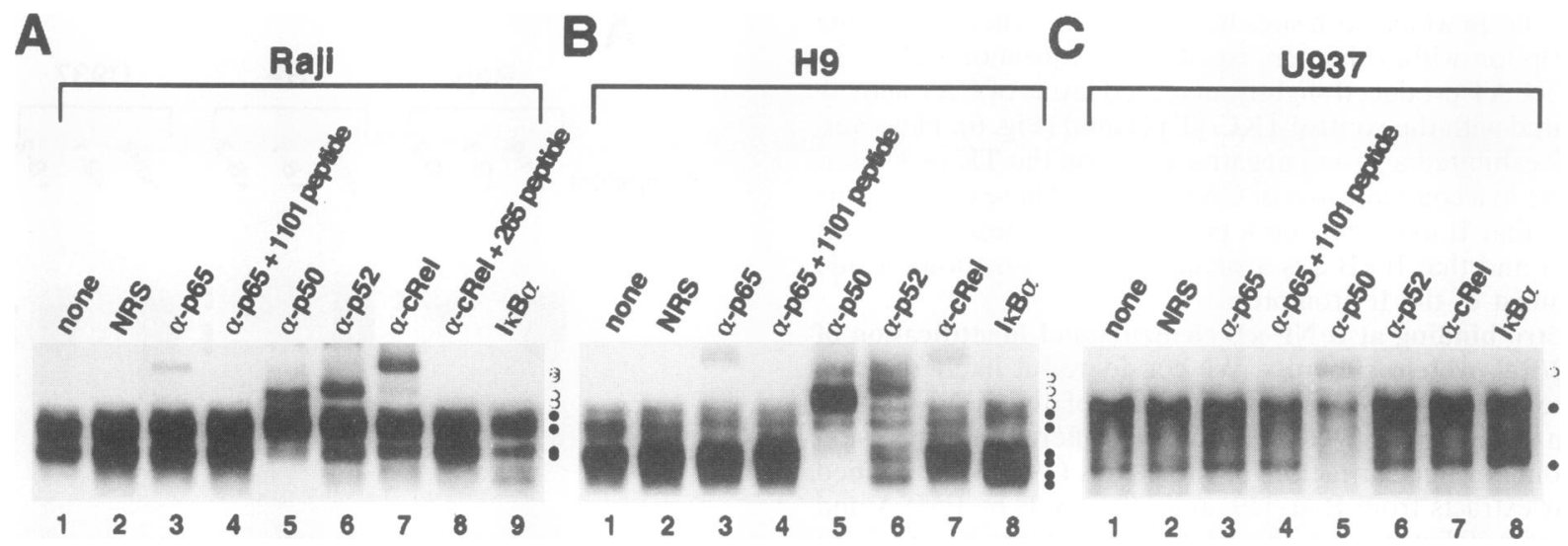

FIG. 8. Iі кB-1-specific complexes contain NF-кB/Rel proteins in different cell lines. Nuclear extracts from Raji (A), H9 (B), and U937 (C) cells were incubated with buffer alone (lane 1); normal rabbit serum (lane 2); specific antibodies against p65 (lane 3 ), p65 in the presence of competitive peptide (lane 4), p50 (lane 5), p52 (lane 6), and c-Rel (lane 7); or IкB $\alpha$ protein (last lane). These reactions were incubated for $2 \mathrm{~h}$ at $4^{\circ} \mathrm{C}$, and then the radiolabeled Ii $\kappa$ B-1 was added. The complexes formed were analyzed by EMSA on nondenaturing polyacrylamide gels. All antibodies were tested with probe alone to identify nonspecific bands (data not shown). Solid circles indicate NF-кB/Rel-specific complexes, and open circles indicate antibody supershifted complexes.

antibodies (Fig. 8B). Ii $\mathrm{\kappa B}-1$ complexes in $\mathrm{H} 9$ reacted weakly with anti-p65, forming a faint supershifted band (lane 3). Antibody to p50 reacted strongly with the lower set of bands such that the entire complex was displaced (lane 5). Anti-p52 also reacted with $\mathrm{H} 9$ complexes. Anti-c-Rel resulted in a faint supershifted band that was not always detectable. Thus, all antibodies appeared to react with $\mathrm{H} 9$-Ii $\kappa \mathrm{B}-1$ complexes, which is a positive regulatory site. The composition of the complex is similar to that of the complex formed in Raji cells; however, the relative amounts of various subunits appear to be different between Raji and $\mathrm{H} 9$ cells.

Ii $\kappa \mathrm{B}-2$-bound $\mathrm{H} 9$ complexes were recognized by anti-p50 and anti-p52 but not by anti-p65 or anti-c-Rel (Fig. 9B). Anti-p50 eliminated both bands and formed a strong supershifted complex, whereas anti-p52 eliminated the upper complex. From these results the lower complex may be a p50-p50 homodimer and the upper band may be a p50-p52 heterodimer on Ii $\kappa$ B-1 in H9 extracts. In contrast to Raji, in vitro binding was readily detectable for both $\mathrm{Ii} \kappa \mathrm{B}-1$ and $\kappa \mathrm{B}-2$ by using $\mathrm{H} 9$ nuclear extracts, which correlates well with the in vivo occupancy of both sites in $\mathrm{H} 9$ cells.

Complexes in U937 were recognized only by the anti-p50 antibody of the four antisera tested (Fig. 8C and 9C). On Ii $\kappa \mathrm{B}-1$ the lower complex was eliminated by anti-p50 while the upper complex was weakly reactive (Fig. 8C). Ii $\kappa \mathrm{B}-2$ bound one complex in U937 cells. This complex was completely eliminated by anti-p50 and was not affected by any other antibodies tested (Fig. 9C). This is similar to findings in a previous study, in which the IL2-R $\alpha$ enhancer NF-кB/Rel site bound p50 in U937 extracts (28). Nuclear extracts from uninduced and IFN- $\gamma$-induced U-105 MG cells were also tested for Ii $\kappa \mathrm{B}$-binding activity. Specific DNA-protein complexes formed in the presence of Ii $\kappa \mathrm{B}-1$ and did not change upon IFN- $\gamma$ treatment (data not shown). The antibodies used in these experiments were unable to shift any of these complexes. Weak binding to the Ii $\mathrm{\kappa B}-2$ probe was observed for the U-105 MG extracts, requiring 10 times the exposures needed

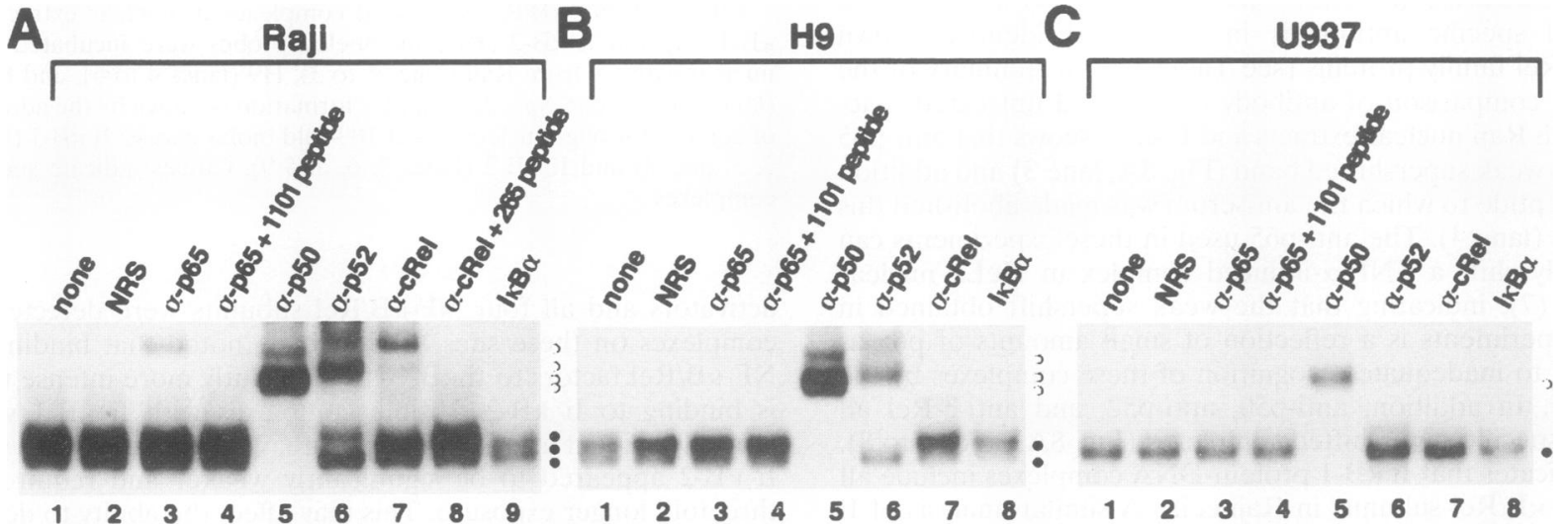

FIG. 9. Ii кB-2-specific complexes contain NF-кB/Rel proteins in different cell lines. Nuclear extracts from Raji (A), H9 (B), and U937 (C) cells were incubated as in Fig. 8 with specific antibodies, controls, or $\mathrm{I} \kappa \mathrm{B} \alpha$ protein as indicated and reacted with radiolabeled Ii $\kappa \mathrm{B}-2$. Complexes were analyzed by EMSA as described in the text. Solid circles indicate NF-кB/Rel-specific complexes, and open circles indicate antibody supershifted complexes. 
for Ii $\kappa$ B-1. Anti-p50 was able to supershift this complex (data not shown).

We also investigated the nature of the DNA-protein complexes by adding purified $\mathrm{I} \kappa \mathrm{B} \alpha(\mathrm{MAD}-3)$ protein to in vitro binding reactions. The addition of IкB $\alpha$ only weakly inhibited the formation of some complexes when Raji nuclear extracts were used; however, other bands remained (Fig. 8A and 9A, last lane of the respective panels). The weak inhibitory effects of $\mathrm{I} \kappa \mathrm{B} \alpha$ on complex formation suggests the presence of small amounts of NF-кB in these complexes, and the inability to abolish these complexes suggests the presence of small amounts of p65 and c-Rel in these extracts, since it has been observed that $\mathrm{I} \kappa \mathrm{B} \alpha$ can associate with and prevent DNA binding of complexes containing p65 and c-Rel (6).

Taken together, these experiments show that the Ii NF-кB/ Rel sites bind NF-kB/Rel subunits in nuclear extracts. A summary of the data is shown in Table 1 . It appears that in cell lines in which Ii NF-kB/Rel sites have a negative regulatory function the complexes formed were recognized only by antisera against p50 and p52, whereas in cell lines in which Ii $\mathrm{NF}-\kappa \mathrm{B} / \mathrm{Rel}$ sites have a positive regulatory function the complexes contained detectable amounts of p65 and c-Rel in addition to p50 and p52. Some DNA-binding complexes were not affected by antibody and may represent unidentified proteins. However, we cannot exclude the possibility that some proteins, when contained in certain complexes, cannot be recognized by these antibodies.

\section{DISCUSSION}

In this study we show for the first time the in vivo genomic footprint of two NF-kB/Rel sites present in the human Ii promoter and demonstrate that they have contrasting regulatory functions in different cell types. We also present extensive analysis of the NF- $\mathrm{B} / \mathrm{Rel}$ complexes formed on these sites in different cell types. Ii $\kappa \mathrm{B}-1$ is a positive regulatory element in Ii-expressing $\mathrm{B}$ - and $\mathrm{T}$-lymphoid cell lines and a negative element in myelomonocytic cell lines, HeLa cells, glioblastoma cells, and primary brain glial cells. Ii $\kappa \mathrm{B}-2$ is a positive regulatory element in $\mathrm{B}$-cell lines and a negative element in $\mathrm{H} 9$ cells, myelomonocytic cell lines, and glioblastoma cells. In vivo footprint analysis revealed binding to proteins at $\mathrm{NF}-\mathrm{\kappa} \mathrm{B} / \mathrm{Rel}$ sites with both positive and negative activity. In addition, in vitro binding studies revealed that both Ii NF- $\mathrm{B} / \mathrm{Rel}$ sites were bound by $\mathrm{NF}-\kappa \mathrm{B} / \mathrm{Rel}$-containing complexes in nuclear extracts from all expressing cells. However, different NF- $\mathrm{B} /$ Rel subunits bound positive sites compared with those that bound negative regulatory sites. Collectively these results indicate that the function of Ii NF-kB/Rel elements appears to correlate with the binding of different known NF-кB/Rel family members in a cell-type-dependent fashion.

NF- $\mathrm{BB} / \mathrm{Rel}$ sites are important cis-acting elements that regulate the expression of a variety of inducible, tissue-restricted, and viral genes (1). The murine Ii NF-kB/Rel site has previously been shown to be a B-cell-specific activator as well as a TNF- $\alpha$-responsive element $(40,52)$. The murine Ii NF$\kappa \mathrm{B} / \mathrm{Rel}$ binding site and human Ii $\kappa \mathrm{B}-1$ are nearly identical, having only a one-nucleotide difference. This study presents observations on the cell-type-specific regulation of the human Ii gene and shows that Ii NF- $\kappa B / R e l$ elements have positive and negative regulatory functions that are cell type dependent.

Ii $\kappa$ B-2 dramatically repressed a heterologous promoter when inserted upstream of the TK promoter in TKCAT plasmids in U937, a promonocytic cell line. Ii $\mathrm{\kappa B}-1$ did not repress the heterologous TK promoter. A likely explanation for these results is that the mechanism of repression by Ii $\mathrm{kB}-1$ may be dependent on the context of the Ii promoter. Interestingly, the function of some NF-kB/Rel sites requires the presence of a separate element that acts from a distance. This mechanism has been described for a Dorsal binding site $(24$, 25 ) and for an immunoglobulin Ig $\kappa B$ site (42). It is possible that Ii $\kappa \mathrm{B}-1$ functions in this way since it is position dependent; however, Ii $\kappa \mathrm{B}-2$ clearly does not have these restrictions.

In vivo protein-DNA interactions and gene expression tend to correlate, as demonstrated in studies of the MHC class I and class II, invariant-chain, tyrosine aminotransferase, muscle creatine kinase, mouse metallothionein I, and mouse transthyretin genes $(5,16,27,33,36,50)$. This correlation is supported by our observations of in vivo interactions on the Ii $\kappa \mathrm{B}-1$ element in expressing B- and T-lymphocytic cell lines and the glioblastoma cell line and the strong interaction on Ii $\kappa \mathrm{B}-2$ in $\mathrm{H} 9$ cells. In some cases an observed in vivo protection does not correlate with induced expression of the gene, as noted on the serum response element of c-fos during induced expression of the gene (15) and the AP-1 site of the collagenase gene (30). In other situations interactions are not observed on known transcriptional elements such as the S element of MHC class II and Ii genes $(12,28)$. In vivo binding was also not observed with $\mathrm{Ii}$ $\kappa \mathrm{B}-2$ in $\mathrm{B}$ cells and the glioblastoma cell line, where the presence of NF- $\mathrm{KB} / \mathrm{Rel}$ proteins in these extracts was demonstrated by in vitro EMSA (Fig. 2 and 9; also data not shown). The absence of in vivo interactions on known regulatory sites may be attributed to technical limitations of the assay or to the inherent low affinity of protein-DNA interactions at this site. The latter is probably the case because in vitro binding of Ii $\kappa \mathrm{B}-2$ is significantly weaker than at $\kappa \mathrm{B}-1$ and requires $3-$ and 10 -fold longer exposures to rival the intensity of Ii $\kappa \mathrm{B}-1$ binding for Raji and U-105 MG nuclear extracts, respectively.

An intriguing observation is the induction of in vivo protections at the negative regulatory element, Ii $\kappa \mathrm{B}-1$, upon IFN- $\gamma$ treatment of the glioblastoma cells. The timing of protein binding to Ii $\kappa \mathrm{B}-1$ is such that maximal binding is delayed until $48 \mathrm{~h}$, which coincides with the decrease in transcription detected after this at 48 to $72 \mathrm{~h}$ in the run-on experiments. During IFN- $\gamma$ induction the endogenous promoter becomes available for factor binding and becomes bound at an array of sites including Ii X, Y, and ISRE at $24 \mathrm{~h}$ after treatment. These results suggest that occupancy of these positive and negative sites during IFN- $\gamma$ induction may be sequential, with binding of the positive sites occurring first and binding of the negative site delayed. Therefore, the occupation of Ii $\kappa \mathrm{B}-1$ may lead to subsequent down-regulation of the Ii gene. Another instance of a repressor NF- $\kappa \mathrm{B} / \mathrm{Rel}$ site which is bound in vivo is the Ii $\kappa \mathrm{B}-2$ site, which has clear protein-DNA interactions in $\mathrm{H} 9$ cells (Fig. 2, bottom panel). Thus, NF-кB/Rel binding to a target site can lead to either enhanced or repressed gene expression.

The detection of in vivo interactions on Ii NF- $\mathrm{kB} / \mathrm{Rel}$ sites that have a negative regulatory role suggests that these elements are bound by proteins that mediate repression. We extensively analyzed complexes formed on Ii NF- $\mathrm{kB} / \mathrm{Rel}$ sites in in vitro binding studies with nuclear extracts from different cell types to assess whether a specific pattern of protein-DNA interactions was associated with a positive or a negative regulatory function (Fig. 7 to 9 ; results are summarized in Table 1). In cells in which the Ii NF-кB/Rel sites were activators, the sites are bound by p50, p52, p65, and c-Rel. The binding of p65 and c-Rel was unique to activator $\mathrm{kB}$ sites and was not observed on the negative sites. Importantly, p65 has been shown to be a strong transactivator through other $\kappa \mathrm{B}$ sites $(3,45,47)$. c-Rel has been shown to have an activation domain but functions only weakly through an NF-кB site. The negative Ii $\kappa \mathrm{B}$ sites bound proteins identified as p50 and p52, which 
correlates with previously published observations. In cotransfection experiments, $\mathrm{p} 50$ overexpression resulted in repression of p65 transactivation (through a promoter containing two $\mathrm{kB}$ sites linked to a truncated c-fos promoter) (45) and repression of an interleukin-2 promoter in EL-4 cells (26). In addition, p50 inhibited induction by TPA (12-O-tetradecanoylphorbol13-acetate) activation through human immunodeficiency virus $\kappa \mathrm{B}$ sites, which was reversed by an IкB, Bcl-3 (20). From previous studies, p50 homodimers have negative regulatory roles on known NF-kB/Rel sites (26) whereas on other sites they appear to be transactivators (21). This correlates with our results, which show that p50 is present in complexes on repressor sites in $\mathrm{H} 9$ and U937 nuclear extracts as well as on activator sites (Table 1). Although the role of p52 in transcription is less clear, it has been shown to transactivate in the presence of p65 $(18,39)$. On the Ii NF- $\mathrm{B} / \mathrm{Rel}$ sites, $\mathrm{p} 52$ is involved in complexes with different functions depending on the cell type. Some complexes were not affected by antibody in these assays, perhaps owing to different protein conformations in complexes with different components. Another possibility is that an undetected or unknown factor(s) is involved in these complexes. Such a factor(s) may determine the cell-typespecific function of the site.

In conclusion, this work demonstrates that the role of Ii $\kappa \mathrm{B}-1$ and $\kappa \mathrm{B}-2$ regulatory elements is cell dependent and probably due to binding of disparate NF- $\mathrm{B} / \mathrm{Rel}$ factors in different cell types. In vivo footprinting detected binding of both activator and repressor sites. Activator functions correlated with the presence of binding activity identified as p65, p50, p52, and c-Rel in lymphocytic cell lines. Repressor functions correlated with the presence of only p50 and p52 binding activity in H9 T cells and U937 promonocytic cells. These proteins are involved in the context of a complicated promoter, which differentially regulates Ii expression in a variety of cell types.

\section{- ACKNOWLEDGMENTS}

This work was supported by National Cancer Institute grant CA48185 and National Multiple Sclerosis Society grant RG1785. J.P.-Y.T. is supported by an American Cancer Society Faculty award. K.L.W. is a recipient of an Arthritis Foundation postdoctoral fellowship. M.W.L. is supported by NIH predoctoral training grant GM08332-03.

\section{REFERENCES}

1. Baeuerle, P. A. 1991. The inducible transcription activator NF-kB: regulation by distinct protein subunits. Biochim. Biophys. Acta 1072:63-80.

2. Baeuerle, P. A., and D. Baltimore. 1991. The physiology of the NF-kB transcription factor, p. 409-432. In P. Cohen and J. G. Foulkes, Hormonal control regulation of gene expression. Elsevier/North Holland Biomedical Press, New York.

3. Ballard, D. W., E. P. Dixon, N. J. Peffer, H. Bogerd, S. Doerre, B. Stein, and W. C. Greene. 1992. The $65-\mathrm{kDa}$ subunit of human $\mathrm{NF}-\mathrm{kB}$ functions as a potent transcriptional activator and a target for v-Rel-mediated repression. Proc. Natl. Acad. Sci. USA 89: 1875-1879.

4. Barr, C. L., and G. F. Saunders. 1991. Interferon- $\gamma$-inducible regulation of the human invariant chain gene. J. Biol. Chem. 266:3475-3481.

5. Becker, P. B., S. Ruppert, and G. Schütz. 1987. Genomic footprinting reveals cell type-specific DNA binding of ubiquitous factors. Cell 51:435-443.

6. Beg, A. A., and A. S. Baldwin, Jr. 1993. The IкB proteins: multifunctional regulators of Rel/NF-kB transcription factors. Genes Dev. 7:2064-2070.

7. Beg, A. A., T. S. Finco, P. V. Nantermet, and A. S. Baldwin, Jr. 1993. Tumor necrosis factor and interleukin-1 lead to phosphor-

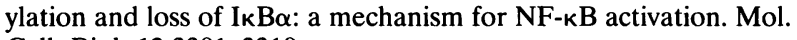
Cell. Biol. 13:3301-3310.

8. Benoist, C., and D. Mathis. 1990. Regulation of major histocompatibility complex class-II genes: X, Y, and other letters of the alphabet. Annu. Rev. Immunol. 8:681-715.

9. Blank, V., P. Kourilsky, and A. Israël. 1992. NF-кB and related proteins: Rel/dorsal homologies meet ankyrin-like repeats. Trends Biochem. Sci. 17:135-140.

10. Bradford, M. M. 1976. A rapid and sensitive method for the quantitation of microgram quantities of protein utilizing the principle of protein-dye binding. Ann. Biochem. 72:248-254.

11. Brown, A. M., C. L. Barr, and J. P.-Y. Ting. 1991. Sequences homologous to class II MHC W, X, and Y elements mediate constitutive and interferon- $\gamma$. induced expression of human class II-associated invariant chain gene. J. Immunol. 146:3183-3189.

12. Brown, A. M., K. L. Wright, and J. P.-Y. Ting. 1993. Human MHC class II associated invariant chain gene promoter: functional analysis and in vivo protein/DNA interactions of constitutive and IFN- $\gamma$ induced expression. J. Biol. Chem. 268:26328-26333.

13. Cresswell, P. 1992. Chemistry and functional role of the invariant chain. Curr. Opin. Immunol. 4:87-92.

14. de Préval, C., B. Lisowska-Grospierre, M. Loche, C. Griscelli, and B. Mach. 1985. A trans-acting class II regulatory gene unlinked to the MHC controls expression of HLA class II genes. Nature (London) 318:291-293.

15. Dey, A., D. W. Nebert, and K. Ozato. 1991. The AP-1 site and the cAMP and serum response elements of the c-fos gene are constitutively occupied in vivo. DNA Cell Biol. 10:537-544.

16. Dey, A., A. M. Thornton, M. Lonergan, S. M. Weissman, J. W. Chamberlain, and K. Ozato. 1992. Occupancy of upstream regulatory sites in vivo coincides with major histocompatibility complex class I gene expression in mouse tissues. Mol. Cell. Biol. 12:35903599.

17. Doyle, C., P. J. Ford, P. D. Ponath, T. Spies, and J. L. Strominger. 1990. Regulation of the class II-associated invariant chain gene in normal and mutant B lymphocytes. Proc. Natl. Acad. Sci. USA 87:4590-4594.

18. Duckett, C. S., N. D. Perkins, T. F. Kowalik, R. M. Schmid, E.-S. Huang, A. S. Baldwin, Jr., and G. J. Nabel. 1993. Dimerization of NF-kB2 with RelA(p65) regulates DNA binding, transcriptional activation, and inhibition by an IkB- $\alpha$ (MAD-3). Mol. Cell. Biol. 13:1315-1322.

19. Eades, A.-M., M. Litfin, and H. J. Rahmsdorf. 1990. The IFN- $\gamma$ response of the murine invariant chain gene is mediated by a complex enhancer that includes several MHC class II consensus elements. J. Immunol. 144:4399-4409.

20. Franzoso, G., V. Bours, S. Park, M. Tomita-Yamaguchi, K. Kelly, and U. Siebenlist. 1992. The candidate oncoprotein Bcl-3 is an antagonist of $\mathrm{p} 50 / \mathrm{NF}-\mathrm{kB}-$ mediated inhibition. Nature (London) 359:339-342.

21. Fujita, T., G. Nolan, S. Ghosh, and D. Baltimore. 1992. Independent modes of transcriptional activation by the p50 and p65 subunits of NF-кB. Genes Dev. 6:775-787.

22. Glimcher, L. H., and C. J. Kara. 1992. Sequences and factors: a guide to MHC class II transcription. Annu. Rev. Immunol. 10:13-50.

23. Grilli, M., J. S. Chiu, and M. J. Lenardo. 1993. NF-кB and Rel-participants in a multiform transcriptional regulatory system. Int. Rev. Cytol. 143:1-62.

24. Ip, Y. T., R. Kraut, M. Levine, and C. A. Rushlow. 1991. The dorsal morphogen is a sequence-specific DNA-binding protein that interacts with a long-range repression element in Drosophila. Cell 64:439-446.

25. Jiang, J., and M. Levine. 1993. Binding affinities and cooperative interactions with bHLH activators delimit threshold responses to the dorsal gradient morphogen. Cell 72:741-752.

26. Kang, S.-M., A.-C. Tran, M. Grilli, and M. J. Lenardo. 1992. NF- $\mathrm{kB}$ subunit regulation in nontransformed CD4 ${ }^{+} \mathrm{T}$ lymphocytes. Science 256:1452-1456.

27. Kara, C. J., and L. H. Glimcher. 1991. In vivo footprinting of MHC class II genes: bare promoter in the bare lymphocyte syndrome. Science 252:709-712.

28. Kaufman, P. A., J. B. Weinberg, and W. C. Greene. 1992. Nuclear 
expression of the 50- and $65-\mathrm{kD}$ Rel-related subunits of nuclear factor- $\mathrm{KB}$ is differentially regulated in human monocytic cells. $\mathbf{J}$. Clin. Invest. 90:121-129.

29. Koch, N., and A. W. Harris. 1984. Differential expression of the invariant chain in mouse tumor cells: relationship to B lymphoid development. J. Immunol. 132:12-15.

30. König, H., H. Ponta, H. J. Rahmsdorf, and P. Herrlich. 1992. Interference between pathway-specific transcription factors: glucocorticoids antagonize phorbol ester-induced AP-1 activity without altering AP-1 site occupation in vivo. EMBO J. 11:2241-2246.

31. Kudo, J., L.-Y. Chao, F. Narni, and G. F. Saunders. 1985. Structure of the human gene encoding the invariant $\gamma$-chain of the class II histocompatibility antigens. Nucleic Acids Res. 13:88278840 .

32. Kunkel, T. A., J. D. Roberts, and R. A. Zakour. 1987. Rapid and efficient site-specific mutagenesis without phenotypic selection. Methods Enzymol. 154:367-382.

33. Mirkovitch, J., and J. E. Darnell, Jr. 1991. Rapid in vivo footprinting technique identifies protein bound to the TTR gene in the mouse liver. Genes Dev. 5:83-93.

34. Momburg, F., N. Koch, P. Möller, G. Moldenhauer, G. W. Butcher, and G. J. Hämmerling. 1986. Differential expression of Ia and Ia-associated invariant chain in mouse tissues after in vivo treatment with IFN- $\gamma$. J. Immunol. 136:940-948.

35. Momburg, F., K. Koretz, A. Von Herbay, and P. Möller. 1988. Nonimmune human cells can express MHC class II antigens in the absence of invariant chain-an immunohistological study on normal and chronically inflamed small intestine. Clin. Exp. Immunol. 72:367-372.

36. Mueller, P. R., and B. Wold. 1989. In vivo footprinting of a muscle specific enhancer by ligation mediated PCR. Science 246:780-786.

37. Neumann, J. R., C. A. Morency, and K. O. Russian. 1987. A novel rapid assay for chloramphenicol acetyltransferase gene expression. BioTechniques 5:444-448.

38. Nolan, G. P. and D. Baltimore. 1992. The inhibitory ankyrin and activator Rel proteins. Curr. Opin. Genet. Dev. 2:211-220.

39. Perkins, N. D., R. M. Schmid, C. S. Duckett, K. Leung, N. R. Rice, and G. J. Nabel. 1992. Distinct combinations of NF-KB subunits determine the specificity of transcriptional activation. Proc. Natl. Acad. Sci. USA 89:1529-1533.

40. Pessara, U., and N. Koch. 1990. Tumor necrosis factor a regulates expression of the major histocompatibility complex class II-associated invariant chain by binding of an NF-кB-like factor to a promoter element. Mol. Cell. Biol. 10:4146-4154.
41. Phares, W., B. R. Franza, Jr., and W. Herr. 1992. The kB enhancer motifs in human immunodeficiency virus type 1 and simian virus 40 recognize different binding activities in human Jurkat and $\mathrm{H} 9 \mathrm{~T}$ cells: evidence for NF- $\mathrm{kB}$-independent activation of the $\kappa \mathrm{B}$ motif. J. Virol. 66:7490-7498.

42. Pierce, J. W., A. M. Gifford, and D. Baltimore. 1991. Silencing of the expression of the immunoglobulin kappa gene in non-B cells. Mol. Cell. Biol. 11:1431-1437.

43. Rice, N. R., M. L. MacKichan, and A. Israël. 1992. The precursor of NF-кB p50 has IкB-like functions. Cell 71:243-253.

44. Sasaki, A., S. W. Levinson, and J. P.-Y. Ting. 1989. Comparison and quantitation of Ia antigen expression on cultured macroglia and ameboid microglia from Lewis rat cerebral cortex: analyses and implications. J. Neuroimmunol. 25:63-74.

45. Schmitz, M. L., and P. A. Baeuerle. 1991. The p65 subunit is responsible for the strong transcription activating potential of NF-кB. EMBO J. 10:3805-3817.

46. Sen, R., and D. Baltimore. 1986. Inducibility of $\kappa$ immunoglobulin enhancer-binding protein NF- $\mathrm{KB}$ by a posttranslational mechanism. Cell 47:921-928.

47. Stein, B., P. C. Cogswell, and A. S. Baldwin, Jr. 1993. Functional and physical associations between NF-kB and C/EBP family members: a Rel domain-bZIP interaction. Mol. Cell. Biol. 13: 3964-3974.

48. Stein, B., H. J. Rahmsdorf, A. Stefien, M. Litfin, and P. Herrlich. 1989. UV-induced DNA damage is an intermediate step in the UV-induced expression of human immunodeficiency virus type 1, collagenase, c-fos, and metallothionein. Mol. Cell. Biol. 9:51695181.

49. Viville, S., J. Neefjes, V. Lotteau, A. Dierich, M. Lemeur, H. Ploegh, C. Benoist, and D. Mathis. 1993. Mice lacking the MHC class II-associated invariant chain. Cell 72:635-648.

50. Wright, K. L. and J. P.-Y. Ting. 1992. In vivo footprint analysis of the HLA-DRA gene promoter: cell-specific interaction at the octamer site and up-regulation of $\mathrm{X}$ box binding by interferon- $\gamma$. Proc. Natl. Acad. Sci. USA 89:7601-7605.

51. Yuan, D., and P. W. Tucker. 1984. Transcriptional regulation of the $\mu-\delta$ heavy chain locus in normal murine B lymphocytes. J. Exp. Med. 160:564-583.

52. Zhu, L., and P. P. Jones. 1990. Transcriptional control of the invariant chain gene involves promoter and enhancer elements common to and distinct from major histocompatibility complex class II genes. Mol. Cell. Biol. 10:3906-3916. 